element of HIVIAIDS prevention. Antiretroviral therapy (ART) is an integral part of medical care for HIV-positive patients.

The aim of our study was to evaluate the impact of psychotic and mental disorders on the effectiveness ART in HIV-infected IDUs with substitution therapy. In the study we included 33 HIV-infected injection drug users, with evaluation degree of mental and psychotic disorders by BPRS and MADRS scales before SMT, ART and after 24 weeks of treatment.

Against the background of SMT to initiation of ART in all patients was marked reduction in the intensity of psychotic and depressive disorders, and after 24 weeks of ART reduction rate reached 12 points for the BPRS, and 6 points on the MADRS, respectively.

After 24 weeks of ART in 25 (75.8\%) patients had achieved a complete suppression of HIV (HIV-RNA $<50$ copies / ml). In 8 (24.2\%) patients had virological registered inefficiency ART. The degree of psychotic and mental disorders on scales in patients with virological ineffectiveness before the appointment of ART was significantly higher than in patients who achieved complete viral suppression, and reached $43(41,5-46,5)$ scores by BPRS, and $16(14-17,5)$ points by MADRS. The majority of patients with psychotic disorders (more than 41 points for BPRS) and / or depressive disorders (more than 14 points on MADRS) did not achieve virological efficacy after 24 weeks of treatment ART. The SMT in HIV-infected IDUs decreased level of psychotic disorders and depression and has positively affects on the virologic effectiveness of ART. Low virological efficacy of ART can be predicted in HIVinfected IDUs in the evaluation on BPRS scores over 41 and / or MADRS score by more than 14 points.

Key words: HIV infection, ART, CD4 cell, methadone, buprenorphine, injecting drug users.

Отримано 25.08.2016 p.

\footnotetext{
() Шмига Т.В., Пукаляк Р.М., Гаєвська В.Ю., Гаєвський В.Ю., 2016 УДК 616.98:576.858.13]-036.87-06:(618.177+616.697)]-036 DOI 10.11603/1681-2727.2016.4.7211
}

Т.В. Шмига, Р.М. Пукаляк, В.Ю. Гаєвська, В.Ю. Гаєвський

\title{
КЛІНІЧНІ ТА ІНФЕКТОЛОГІЧНІ ОСОБЛИВОСТІ ХВОРИХ 3 РЕЦИДИВНОЮ АКТИВОВАНОЮ ГЕРПЕТИЧНОЮ ІНФЕКЦІЮ 1/2 ТИПУ ТА БЕЗПЛІДДЯМ
}

Львівський національний медичний університет ім. Данила Галицького, Львівський обласний клінічний діагностичний центр

Обстежено 120 хворих з рецидивною активованою герпетичною інфекцією 1/2 типу, серед яких безпліддя було діагностоване у 63 пацієнтів. Виявлено, що клінічні прояви рецидивної інсрекції вірусу простого герпесу (ВПГ) 1/2, особливо дерматологічного характеру, найбільше виражені у безплідних хворих, для яких були характерні часті рецидиви ВПГ 1/2, наявність ДНК ВПГ 1/2 у всіх досліджуваних клінічних зразках (слині, крові й зскрібках з місць уражень) та підвищені титри IgG у сироватці крові.

Ключові слова: простий герпес, клініка, рецидив, безпліддя.
Існування інсрекції в організмі жінки або чоловіка $є$ однією із серйозних причин безпліддя, яке вивчається і лікарями-практиками, і величезними науковими інститутами в різних країнах: ведуться спостереження, створюються спеціальні програми. Статистичні дані ВООЗ свідчать, що з проблемою безпліддя за весь репродуктивний період життя стикається до 8 \% подружніх пар у всьому світі [1-3]. У більшості випадків причини безпліддя залишаються невідомими [4]. Існує все більше доказів того, що вірусні інорекції відіграють певну роль в патогенезі чоловічого і жіночого безпліддя [2, 3, 5]. Серед мікроорганізмів, які колонізують у чоловічих і 
жіночих статевих шляхах, є ВПГ 1/2, які найбільш поширені в людській популяції і відповідають за цілий ряд захворювань, в тому числі й захворювань статевих органів, які можуть сприяти безпліддю [6-8].

Простий герпес спричинює широкий спектр уражень в організмі інфрікованої людини [8-10]. У деяких пацієнтів можливі рецидиви герпетичної інфекції внаслідок реактивації ВПГ [10, 11]. Клінічні прояви рецидивного герпесу залежать від локалізації патологічного процесу та його розповсюдженості, стану імунної системи $[7,12]$. Відомі різні клінічні форми герпетичної інорекції: ураження шкіри різноманітної локалізації, слизової оболонки ротової порожнини, статевих органів, очей, центральної та периферичної нервової системи, а також вісцеральні фрорми (пневмонія, гепатит, енцесраліт тощо) [8]. Найбільш клінічно розповсюдженими є прояви, що спостерігаються на шкірі та слизових оболонках [13]. Більш тяжкі форми пов'язані з ураженням очей, геніталій, внутрішніх органів та центральної нервової системи [9, 14].

Герпетичні захворювання органів сечостатевої системи відіграють важливу роль у патології репродуктивної медицини. Хронічна рецидивна інсекція ВПГ призводить до розвитку хронічних запальних процесів урогенітального тракту, що своєю чергою впливає на репродуктивне здоров'я жінки та чоловіка та є одним з фракторів фрормування чоловічого та жіночого безпліддя [2, 3]. Встановлено, що простий герпес і безпліддя тісно пов'язані, і саме у носіїв вірусу фрертильність знижена практично вдвічі [1, 2, 5, 6, 15].

Одною з можливих причин безпліддя вважають порушення роботи імунної системи [12]. За останні 1015 років у патології безпліддя значна роль відводиться порушенням з боку імунної системи, однак у теперішній час залишаються недостатньо вивченими патогенетичні аспекти безпліддя, зумовлені імунологічними фракторами. Передбачають, що нерозпізнані імунні порушення частіше за все є причиною ідіопатичного безпліддя [6].

\section{Пацієнти і методи}

Проведено проспективне дослідження 120 хворих, віком від 35 років - старше 50 років, 3 хронічною реактивованою герпетичною інфекцією ВПГ 1/2. Всі обстежені хворі на ВПГ 1/2 поділялись за репродуктивною здатністю: 3 них було 57 (47,5 \%) безплідних, серед яких 22 (38,6 \%) чоловіки і 35 (61,4 \%) жінок, та 63 (52,5\%) плідних - 19 $(30,2 \%)$ чоловіків і 44 (69,8 \%) жінки. У 21 шлюбної пари діагностоване ідіопатичне безпліддя.

Контрольну групу складали 20 здорових осіб відповідного віку. Критеріями включення в контрольну групу були: відсутність симптомів і маніфестації герпетичної інфекції протягом як мінімум останнього року; відсутність гострих інфекцій протягом як мінімум 1 міс. до моменту взяття крові; відсутність хронічних запальних і автоімунних захворювань.

Діагноз встановлювали з урахуванням комплексу клінічних обстежень і загально-лабораторних, інструментальних, імунологічних (на основі протоколу), молекулярногенетичних досліджень та підтверджували виявленням у сироватці крові специфічних серологічних маркерів ВПГ: IgM (позитивний) та IgG (більший у 5 разів від норми), ДНК ВПГ 1/2 (слина, зскрібок з місця ураження, кров). Антитіла класу IgM та IgG визначали за допомогою методу імуноферментного аналізу згідно з методичними рекомендаціями, що додаються до стандартних наборів реактивів «Вектор ВПГ-IgG» та «Вектор ВПГ-IgМ» («Вектор Бест», Росія). Виявлення ДНК ВПГ 1/2 здійснювали за допомогою полімеразної ланцюгової реакції (ПЛР) згідно з методичними рекомендаціями, що додаються до стандартних наборів реактивів «UBI» (США). Матеріалом досліджень при цьому слугували: слина, зскрібок з місця ураження та кров. Клініко-патологічні форми перебігу ВПГ 1/2 визначали згідно зі загальноприйнятими в клінічній практиці критеріями (МКБ10).

Статистична обробка отриманих результатів досліджень проводилася з використанням загальноприйнятих методів варіаційної статистики за допомогою пакету статистичних програм «Excel-2002» і «STATISTIKA for Windows» (Statsoft Ins, США) [16]. Рівень вірогідності визначали за критерієм Ст'юдента [17].

\section{Результати досліджень та їх обговорення}

Проведений аналіз клінічної картини захворювання на рецидивну інсекцію ВПГ 1/2 у безплідних та плідних хворих (табл. 1) показав, що клінічні прояви ВПГ 1/2 були найбільше виражені у безплідних, що може свідчити про існування тісного зв'язку простого герпесу 3 безпліддям і співпадає з даними літератури [2, 5, 6, 15]. Достовірних відмінностей серед досліджуваних груп пацієнтів не було виявлено тільки у характері загальних проявів, за винятком загальної втоми, яка спостерігалась у $(63,2 \pm 13,2) \%$ безплідних хворих. Серед усього спектру клінічних проявів у безплідних хворих найбільше вираженими були дерматологічні, а саме: висипи та набряки були у $(16,30 \pm 4,12)$ та у $(27,20 \pm 4,24) \%(p<0,01)$ пацієнтів, що є характерним для більшості хворих на герпетичну інсекцію [14]. Неврологічні прояви у них зокрема характеризувались полінейропатіями $(14,00 \pm 3,35) \%, p<0,01)$, які були відсутні у плідних. У значної частини безплідних спостерігали неврит сідничного нерва, болі голови та почервоніння очей $(p<0,05)$.

У всіх безплідних чоловіків і жінок з інфекцією ВПГ 1/2 виявлені захворювання органів сечостатевої системи, чого не спостерігалось у переважної більшості 
плідних хворих (табл. 1). Більш вираженими захворювання урогенітального тракту були у безплідних чоловіків, у яких найчастіше зустрічався простатит $(19,60 \pm 4,52) \%, p<0,01$. Серед безплідних жінок найбільше було хворих 3 вагінітом $(16,70 \pm 5,22 \%, p<0,05)$ і сальпінгітом $(13,2 \pm 4,2 \%, p<0,05)$. Вважають, що одним із фракторів формування чоловічого та жіночого безпліддя є хронічні запальні процеси урогенітального тракту, спричинені інфекцією [2, 3], що і було підтверджено результатами наших досліджень.

Таблиця 1

Клінічні прояви активованої рецидивної герпетичної інфекції першого/другого типу у хворих з різною

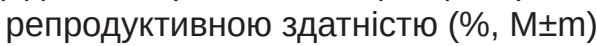

\begin{tabular}{|c|c|c|c|}
\hline & \multirow{2}{*}{ Клінічні прояви } & \multicolumn{2}{|c|}{ Хворі $(n=120)$} \\
\hline & & плідні (n=63) & безплідні (n=57) \\
\hline \multirow{5}{*}{ Загальні } & Втома & $20,00 \pm 9,08$ & $63,20 \pm 13,20^{*}$ \\
\hline & Слабкість & $18,20 \pm 4,73$ & $60,00 \pm 20,40$ \\
\hline & Субфебрильна температура & $11,60 \pm 4,43$ & $43,30 \pm 19,20$ \\
\hline & Болі у суглобах & $0,00 \pm 0,00$ & $4,42 \pm 1,93$ \\
\hline & Болі у м'язах & $0,00 \pm 0,00$ & $5,33 \pm 2,15$ \\
\hline \multirow{6}{*}{ Дерматологічні } & $\begin{array}{l}\text { Висип на : } \\
\text { • статевих органах }\end{array}$ & $10,50 \pm 2,94$ & $20,20 \pm 9,46$ \\
\hline & • губах & $0,00 \pm 0,00$ & $17,50 \pm 7,63^{\star}$ \\
\hline & • інших частинах тіла & $0,00 \pm 0,00$ & $16,30 \pm 4,12^{\star \star}$ \\
\hline & Свербіж & $4,92 \pm 3,35$ & $10,00 \pm 9,43$ \\
\hline & Набряк губ & $5,82 \pm 1,40$ & $16,70 \pm 3,23^{\star \star}$ \\
\hline & Набряки інших частин тіла & $0,00 \pm 0,00$ & $27,20 \pm 4,24^{\star \star}$ \\
\hline \multirow{5}{*}{ Неврологічні } & Полінейропатії & $0,00 \pm 0,00$ & $14,00 \pm 3,35^{\star \star}$ \\
\hline & Неврит сідничного нерва & $1,89 \pm 0,67$ & $9,79 \pm 2,93^{\star}$ \\
\hline & Неврит лицевого нерва & $0,00 \pm 0,00$ & $2,62 \pm 1,51$ \\
\hline & Біль голови & $11,00 \pm 4,60$ & $23,20 \pm 3,21^{*}$ \\
\hline & Почервоніння очей & $0,00 \pm 0,00$ & $9,60 \pm 4,89 *$ \\
\hline \multirow{8}{*}{ Репродуктивні } & $\begin{array}{l}\text { Жінки } \\
\text { • вагініт }\end{array}$ & $5,30 \pm 2,13$ & $16,70 \pm 5,22^{*}$ \\
\hline & • цервіцит & $0,00 \pm 0,00$ & $8,820 \pm 3,61^{*}$ \\
\hline & - ендометрит & $0,00 \pm 0,00$ & $2,63 \pm 1,52$ \\
\hline & - сальпінгіт & $0,00 \pm 0,00$ & $13,20 \pm 4,20 *$ \\
\hline & $\begin{array}{l}\text { Чоловіки: } \\
\text { - уретрит }\end{array}$ & $5,30 \pm 2,13$ & $16,70 \pm 5,22^{*}$ \\
\hline & • епідидиміт & $0,00 \pm 0,00$ & $12,80 \pm 4,31^{\star}$ \\
\hline & • простатит & $0,00 \pm 0,00$ & $19,60 \pm 4,52^{\star \star}$ \\
\hline & • орхіт & $3,08 \pm 1,23$ & $13,20 \pm 3,20 *$ \\
\hline
\end{tabular}

Примітка: * $-p<0,05 ;$ ** - p<0,01 (вірогідна різниця між групами хворих).

Одним з показників тяжкості перебігу рецидивного простого герпесу є частота рецидивів. У таблиці 2 продемонстровані показники частоти рецидивів активованої герпетичної інсрекції 1/2 типу у хворих досліджуваних груп. Для більшої кількості обстежених хворих характерна помірно-рецидивна герпетична інорекція (1-5 рецидивів на рік). Найчастіше (6 і більше рецидивів на рік) рецидиви спостерігались у безплідних хворих $(60,30 \pm 9,45 \%, p<0,001)$ та у меншої кількості плідних $(39,30 \pm 3,75 \%, p<0,05)$. Отримані дані можуть свідчити про диссрункцію імунної системи у безплідних хворих, на існування якої при рецидивах герпетичної інфекції і вказує ряд авторів [10, 11].
Порівняння показників лейкоцитарної формули хворих $з$ активованою рецидивною герпетичною інфекцією 1/2 типу виявило певні відмінності між безплідними і плідними пацієнтами (табл. 3). У безплідних спостерігалось зменшення загальної кількості лейкоцитів $(p<0,05)$, за рахунок зниження абсолютних величин нейтрофрілів ( $<<0,01)$, зокрема сегментоядерних в абсолютних і відносних значеннях $(p<0,01)$, і відносних величин моноцитів $(\mathrm{p}<0,01)$ та зростання рівня лімфроцитів $(p<0,05)$ за відносними показниками порівняно зі здоровими особами. Показники плідних пацієнтів носили недостовірний характер, за винятком паличкоядерних нейтрофрілів, відносна кількість яких була 
Показники частоти рецидивів (\%) активованої рецидивної герпетичної інорекції

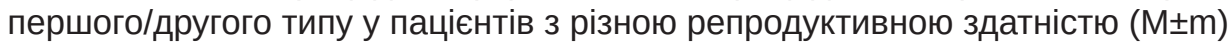

\begin{tabular}{|c|c|c|c|}
\hline \multirow{2}{*}{\multicolumn{2}{|c|}{ Обстежені групи хворих (n=120): }} & \multicolumn{2}{|c|}{ Кількість рецидивів на рік: } \\
\hline & & $1-5(n=83)$ & 6 і більше $(n=37)$ \\
\hline \multicolumn{2}{|l|}{ Хворі } & $34,60 \pm 4,46$ & $30,80 \pm 3,73$ \\
\hline \multirow{2}{*}{$\begin{array}{l}\text { Репродуктивна } \\
\text { здатність }\end{array}$} & плідність (n = 63) & $35,30 \pm 4,62$ & $39,30 \pm 3,75^{\star}$ \\
\hline & безпліддя $(\mathrm{n}=57)$ & $20,00 \pm 6,22$ & $60,30 \pm 9,45$ *** \\
\hline
\end{tabular}

Примітка: * $-p<0,05 ;$ *** $-p<0,001$ (вірогідна різниця між групами хворих).

підвищена $(p<0,05)$ порівняно з контролем. Плідні та безплідні хворі достовірно відрізнялись $(p<0,05)$ між собою за відносними та абсолютними значеннями сегментоядерних гранулоцитів, рівень яких був знижений у безплідних, та лімфоцитів, яких було більше у безплідних. Отримані дані можуть бути свідченням порушення співвідношення та фрункціональної активності основних класів лейкоцитів, зумовлених герпетичною інфекцією, що співпадає з існуючими даними літератури $[8,9]$.

Таблиця 3

Лейкоцитарна фрормула хворих з активованою рецидивною герпетичною інфекцією першого/другого типу залежно від плідності (M $\pm \mathrm{m})$

\begin{tabular}{|c|c|c|c|c|}
\hline \multirow[b]{2}{*}{ Показник } & \multirow{2}{*}{$\begin{array}{c}\text { Одиниця } \\
\text { виміру }\end{array}$} & \multirow{2}{*}{$\begin{array}{l}\text { Здорові } \\
(\mathrm{n}=20)\end{array}$} & \multicolumn{2}{|c|}{ Хворі $(n=120)$ : } \\
\hline & & & $\begin{array}{c}\text { плідні } \\
(\mathrm{n}=63) \\
\end{array}$ & $\begin{array}{c}\text { безплідні } \\
(\mathrm{n}=57)\end{array}$ \\
\hline Лейкоцити: & Г/л & $5,31 \pm 0,43$ & $4,72 \pm 0,52$ & $4,12 \pm 0,27$ * \\
\hline \multirow{2}{*}{ Нейтрофріли: } & $\%$ & $63,00 \pm 5,02$ & $57,00 \pm 5,25$ & $47,00 \pm 4,01$ \\
\hline & Г/л & $3,35 \pm 0,31$ & $2,69 \pm 0,29$ & $1,94 \pm 0,18$ ** \\
\hline \multirow{2}{*}{ паличкоядерні } & $\%$ & $3,53 \pm 0,42$ & $5,14 \pm 0,73$ * & $6,50 \pm 1,01$ * \\
\hline & Г/л & $0,19 \pm 0,03$ & $0,24 \pm 0,08$ & $0,30 \pm 0,10$ \\
\hline \multirow{2}{*}{ сегментоядерні } & $\%$ & $59,50 \pm 5,41$ & $51,90 \pm 6,09$ & $40,50 \pm 3,91 * \star 1$ \\
\hline & Г/л & $3,16 \pm 0,29$ & $2,45 \pm 0,29$ & $1,67 \pm 0,11$ **^ \\
\hline \multirow{2}{*}{ Еозинофріли } & $\%$ & $2,83 \pm 0,82$ & $3,81 \pm 0,92$ & $4,60 \pm 1,22$ \\
\hline & Г/л & $0,15 \pm 0,02$ & $0,18 \pm 0,04$ & $0,20 \pm 0,06$ \\
\hline \multirow{2}{*}{ Базофріли } & $\%$ & $0,52 \pm 0,04$ & $0,25 \pm 0,08$ & $0,17 \pm 0,10$ \\
\hline & Г/л & $0,03 \pm 0,01$ & $0,010 \pm 0,006$ & $0,010 \pm 0,004$ \\
\hline \multirow{2}{*}{ Моноцити } & $\%$ & $7,01 \pm 2,94$ & $4,01 \pm 1,02$ & $2,89 \pm 0,69$ ** \\
\hline & Г/л & $0,37 \pm 0,10$ & $0,19 \pm 0,10$ & $0,12 \pm 0,08$ \\
\hline \multirow{2}{*}{ Лімсроцити } & $\%$ & $32,30 \pm 4,54$ & $33,30 \pm 4,08$ & $44,00 \pm 5,02 * \wedge$ \\
\hline & Г/л & $1,71 \pm 0,12$ & $1,57 \pm 0,10$ & $2,11 \pm 0,21 * \wedge$ \\
\hline
\end{tabular}

Примітка: * - p<0,05; ** - p<0,01 (вірогідна різниця по відношенню до контролю); $\wedge$ - p<0,05 (вірогідна різниця між групами хворих).

Особливість клінічних проявів вірусної інфрекції значною мірою залежить від кількості збудника та стадії його реплікативної активності [7]. Молекулярно-генетична діагностика на основі полімеразно-ланцюгової реакції дозволяє верифікувати діагноз герпесвірусної інфекції. Результати якісного виявлення специфічної ДНК ВПГ 1/2 у крові, слині і зішкрябах з місць уражень хворих 3 рецидивною герпетичною інфекцією 1/2 типу представлено у таблиці 4. Аналіз отриманих результатів у плідних хворих на ВПГ 1/2 показав, що ДНК ВПГ 1/2 виявлялась у крові тільки у 4,94 \% (p<0,001) цих пацієнтів. Результати вивлення ДНК цього вірусу у слині і зскрібках з місць уражень у даних хворих були недостовірними. Навпаки, у безплідних хворих ДНК ВПГ 1/2 виявлялась у всіх досліджуваних клінічних зразках, проте найбільше цього вірусу було (p<0,001) у слині $(83,3 \%)$ та крові $(89,9 \%)$ і менше $(p<0,01)$ у зскрібках 3 місць уражень $(76,5 \%)$. Присутність ДНК ВПГ 1/2 в організмі безплідних хворих може бути свідченням причетності цього вірусу до порушення репродукції, про що і повідомляє ряд джерел літератури [6, 18, 19].

При порівнянні результатів ПлР на відсутність і наявність ДНК ВПГ 1/2 у досліджуваних клінічних зразках достовірно відрізнялись між собою тільки дані ПлР 


\section{ОРИГІНАЛЬНІ ДОСЛІДЖЕННЯ}

плідних хворих, у яких була виявлена вірогідна різниця між: -ДНК-слина і -ДНК-зскрібок та +ДНК-слина і +ДНКзскрібок; -ДНК-слина і -ДНК-кров та +ДНК-слина і +ДНКкров. Аналогічні результати безплідних хворих були недостовірні. Не було вірогідної різниці між: -ДНКзскрібок і -ДНК-кров та +ДНК-зскрібок і +ДНК-кров у плідних і безплідних хворих.

За результатами виявлення ДНК ВПГ 1/2 у крові, слині і зскрібках з місць уражень плідні та безплідні хворі достовірно відрізнялись між собою, найбільше $(p<0,01)$ за вмістом ДНК ВПГ 1/2 у зскрібках 3 місць уражень і в меншій мірі $(p<0,05)$ - за виявленням даного вірусу у слині. Результати порівняння присутності ДНК ВПГ 1/2 у крові плідних і безплідних хворих носили недостовірний характер.

Відсутність ДНК ВПГ 1/2 у крові, слині та зскрібках 3 місць уражень достовірно відрізняла плідних хворих від безплідних. Найбільша відмінність $(p<0,01)$ виявлена при порівнянні результатів ПЛР цих хворих у слині та зскрібках з місць уражень. Менше плідні та безплідні хворі відрізнялись $(p<0,05)$ за відсутністю ДНК ВПГ 1/2 у крові.

Таблиця 4

Вміст ДНК ВПГ 1/2 типів у крові, слині і зскрібках з місць уражень плідних та безплідних хворих 3 активованою рецидивною герпетичною інфрекцією першого/другого типу (\%, M \pm m)

\begin{tabular}{|c|c|c|c|c|c|c|c|}
\hline \multirow{2}{*}{\multicolumn{2}{|c|}{ Обстежені групи хворих }} & \multicolumn{2}{|c|}{ Слина } & \multicolumn{2}{|c|}{ Зскрібок } & \multicolumn{2}{|c|}{ Кров } \\
\hline & & $-Д Н К$ & + +ДНК & -ДНК & + मНК & -ДНК & + ДНК \\
\hline \multicolumn{2}{|c|}{ Кількість хворих (n=120) } & $n=32$ & $n=88$ & $n=45$ & $n=75$ & $\mathrm{n}=110$ & $\mathrm{n}=10$ \\
\hline \multirow[b]{2}{*}{$\begin{array}{c}\text { Репродуктивна } \\
\text { здатність: }\end{array}$} & $\begin{array}{c}\text { плідність } \\
(\mathrm{n}=63)\end{array}$ & $\begin{array}{c}44,40 \pm \\
3,72\end{array}$ & $\begin{array}{c}55,60 \pm \\
9,72\end{array}$ & $\begin{array}{c}49,50 \pm \\
5,72\end{array}$ & $\begin{array}{c}50,50 \pm \\
4,74\end{array}$ & $\begin{array}{c}95,10 \pm \\
15,72\end{array}$ & $\begin{array}{c}4,94 \pm \\
2,54^{\star \star} V^{\wedge}\end{array}$ \\
\hline & $\begin{array}{c}\text { безпліддя } \\
\quad(n=57)\end{array}$ & $\begin{array}{c}16,70 \pm \\
2,78\end{array}$ & $\begin{array}{c}83,30 \pm \\
15,20 \\
\star \star\end{array}$ & $\begin{array}{c}23,50 \pm \\
5,22\end{array}$ & $\begin{array}{c}76,50 \pm \\
9,30 \\
*\end{array}$ & $\begin{array}{c}10,10 \pm \\
3,72\end{array}$ & $\begin{array}{c}89,90 \pm \\
4,33 \\
\star *\end{array}$ \\
\hline
\end{tabular}

Примітки: -ДНК - відсутність ДНК ВПГ 1/2 у клінічному зразку; +ДНК - наявність ДНК ВПГ 1/2 у клінічному зразку; * - p<0,01; ** - p<0,001 (вірогідна різниця між -ДНК та +ДНК у клінічних зразках кожної групи хворих);

V - p<0,05 (вірогідна різниця між: -ДНК-слина і -ДНК-зскрібок та +ДНК-слина і +ДНК-зскрібок у межах кожної групи хворих);

^ - p<0,05 (вірогідна різниця між -ДНК-слина і -ДНК-кров та +ДНК-слина і +ДНК-кров у межах кожної групи хворих).

Значну роль у формуванні специфрічного імунітету проти герпесвірусів відіграють специфрічні антитіла імуноглобуліни класів M (IgM) та G (IgG), головна фрункція яких - захист організму від інсрекційних збудників бактерійної, вірусної етіології та продуктів їхньої життєдіяльності шляхом опсонізації, запуску системи фрагоцитозу та комплементу $[9,10]$. У патології безпліддя значна роль відводиться порушенням з боку імунної системи
[12]. У таблиці 5 наведено титри IgM, IgG у сироватці крові плідних та безплідних хворих з рецидивною іноекцією ВПГ 1/2. У цих хворих спостерігалося достовірне підвищення, порівняно зі здоровими, кількості IgG, показники якого були вищими у безплідних хворих. Отримані дані можуть бути свідченням хронізації інфекції, так як IgG є антитілами вторинної імунної відповіді, яка реалізується при контакті з уже знайомим антигеном [14].

Таблиця 5

Вміст імуноглобулінів класів M та G у сироватці крові хворих з активованою рецидивною герпетичною інфекцією першого/другого типу залежно від плідності (M \pm m)

\begin{tabular}{|l|c|c|c|}
\hline \multirow{2}{*}{ Показник } & \multirow{2}{*}{ Здорові $(\mathrm{n}=20)$} & \multicolumn{2}{|c|}{ Хворі $(\mathrm{n}=120):$} \\
\cline { 3 - 4 } & & плідні $(\mathrm{n}=63)$ & безплідні $(\mathrm{n}=57)$ \\
\hline $\lg \mathrm{M}$ & $0,21 \pm 0,15$ & $0,35 \pm 0,13$ & $0,11 \pm 0,10$ \\
\hline $\lg \mathrm{G}$ & $0,74 \pm 0,27$ & $22,50 \pm 4,22$ ** & $29,50 \pm 6,35^{\star \star *}$ \\
\hline
\end{tabular}

Примітка: ** - p<0,01; *** - p<0,001 (вірогідна різниця по відношенню до контролю).

\section{Висновки}

1. Клінічні прояви рецидивної інсрекції ВПГ 1/2, особливо дерматологічного характеру, найбільше виражені у безплідних хворих.
2. Часто рецидивна інорекція ВПГ 1/2 спостерігається у безплідних хворих і незначної частини плідних.

3. При рецидивній інфекції ВПГ 1/2 у крові безплідних хворих зменшена загальна кількість лейкоцитів. 
4. В організмі безплідних хворих, на відміну від плідних, присутня ДНК ВПГ 1/2, найбільша кількість якої виявлялась у слині та крові, і в меншій мірі у зскрібках 3 місць уражень.

5. У сироватці крові плідних хворих на рецидивну інсрекцію ВПГ 1/2 підвищені титри IgG.

\section{Література}

1. Monavari, S. H., Vaziri, M. S., Khalili, M. (2013). Asymptomatic seminal infection of herpes simplex virus: impact on male infertility. $J$. Biomed. Res., 27(1), 56-61.

2. Brookings, C., Goldmeier, D., Sadeghi-Nejad, H. (2013). Infections transmitted by sex and sexual functions in relation to male fertility. Korean J. Urol., 54, 149-156.

3. Rusz, A., Wagenlehner, F., Linn, T. (2012). The impact of urogenital infections and inflammation in semen quality and male fertility. World. J. Urol., 30, 23-30.

4. Черкасова В. С. (2011). Герпетична інсрекція: клініко-імунологічні та психосоматичні особливості. Український медичний альманах, 14(1), 221-223.

5. Науменко, В. А., Кущ, А. А. (2013). Герпесвирусы и мужское бесплодие: есть ли связь? Вопросы вирусологии, 58(3), 4-9.

6. Цибизов, А. С., Абдулмеджидова, А. Г., Краснопольская, К. В., Гаджиева, 3. С. (2011). Обнаружение вируса простого герпеса в сперматозоидах человека коррелирует со снижением частоты соормирования бластоцист и частоты имплантации эмбрионов при экстракорпоральном оплодотворении. Онтогенез, 42(6), 447-452.

7. Чемич, М. Д., Ільїна, В. В., Лимарь, М. В. (2016). Клінікоепідеміологічні особливості герпесвірусної інфрекції. Інфрекційні хвороби, 1, 23-27.

8. Horowitz, R., Aierstuck, S., Williams, E. A. (2010). Herpes simplex virus infection in a university health population: clinical manifestations, epidemiology, and implications. J. Am. Coll. Health., 59(2), 69-74

9. Марданлы, С. Г., Кирпичникова, Г. И., Неверов, В. А. (2010). Герпетическая инфекция (простой герпес). 2-е изд., испр. и доп.: Электрогорск: ЗАО «ЭКОлаб», 56.

10. Grinde, B. (2013). Herpesviruses: latency and reactivation viral strategies and host response. J. Oral. Microbiol., 5, 4-10.

11. Bennett, J. M., Glaser, R., Malarkey, W. B. (2012). Inflammation and reactivation of latent herpesviruses in older adults. Brain. Behav. Immun., 26(5), 739-746.

12. Retamal-Díaz, A. R., Suazo, P. A., Garrido, I. (2015). Immune evasion by herpes simplex virus. Rev. Chil. Infectol., 32(1), 58-71.
13. Халдин, А. А., Иванов, О. Л., Львов, А. Н. (2010). Дерматологический синдром герпетической болезни: классификация, терминология и терапия (размышления о проблеме). Росс. журн. кож. вен. бол. (прил. герпес), 1, 4-6.

14. Рябчук, Ф. Н., Пирогова, З. И. (2011). Клинико-лабораторная характеристика персистирующих фрорм герпесвирусной иноекции у детей. Лечащий врач, 8, 62-65.

15. Garolla, A., Pizzol, D., Bertoldo, A. (2013). Sperm viral infection and male infertility: focus on HBV, HCV, HIV, HPV, HSV, HCMV and AAV. J. Reprod. Immunol., 100, 20-29.

16. Реброва, О. Ю. (2002). Статистический анализ медицинских данных. Применение пакета прикладных програм STATISTICA. М.: Медиассрера, 312.

17. Гланц С. (1998). Медико-биологическая статистика. М.: Практика, 459.

18. Salehi-Vazyri, M., Monavari, S. H., Khalili, M. (2010). Detection of HSV-1 DNA in the sperm of men with infertility and assess its correlation with semen parameters in Iran. Ir. J. Virol., 4, 1-6.

19. Kato, T., Jinxing, L. U., Fan J. (2013). Detection of human herpesvirus (HHVs) in human sperm of infertile males. J. Reprod. Dev., 59(5), 457-462.

\section{CLINICAL FEATURES AND INFECTOLOGY PATIENTS WITH RECURRENT HERPES INFECTION ACTIVATED FIRST/SECOND TYPE AND INFERTILITY}

T.V. Shmyha, R.M. Pukalyak, V.Y. Hayevska, V.Y. Hayevsky

Lviv National Medical University named Danylo Halician, Lviv Regional Clinical Diagnostic Center

SUMMARY. The study involved 120 patients with recurrent herpes infection activated 1/2 type, including infertility was diagnosed in 63 patients. Found that recurrent clinical manifestations of infection with HSV 1/2, especially dermatological nature, most pronounced in infertile patients, which were characterized by frequent recurrences of HSV 1/2, presence DNA of HSV 1/2 in all studied clinical samples (saliva, blood and zishkryabah places of lesions) and elevated titers of $\lg G$ in serum. Key words: herpes simplex, clinical relapse, infertility.

Отримано 25.08.2016 р. 